\title{
Effect of volume-weight on apparent ileal and excreta amino acid digestibility and feeding value of barley for poultry*
}

\author{
S. Perttilä, J. Valaja, K. Partanen and T. Jalava \\ MTT Agrifood Research Finland, Animal Production Research \\ FIN-31600 Jokioinen, Finland
}

(Reccived 17 April 2001; accepted 6 November 2001)

\section{ABSTRACT}

A total of 185 Ross broiler chickens (age 22 days) and 36 adult Leghorn cockerels were used to investigate the effect of volume-weight (from 53.4 to $71.5 \mathrm{~kg} / \mathrm{hl}$ ) on the apparent excreta digestibility (AED) of nutrients and apparent nitrogen corrected metabolizable energy value ( $A M E_{n}$ ) of barleys. Furthermore, apparent ileal (AID) and AED of amino acids were determined for broilers. Birds were given either a semi-purified soyabean meal based basal diet (crude protein 300 and $170 \mathrm{~g} / \mathrm{kg}$ dry matter for broilers and cockerels, respectively) or basal diet-barley mixtures (50:50 on a DM basis). The AID and AED of nutrients were determined using chromium mordanted straw as an indigestible marker. The AID of nutrients was measured by the slaughter technique. Volume-weight did not affect the AID or AED of amino acids in broilers. Neither did volume-weight affect the $\mathrm{AME}_{n}$ of barley in broilers or cockereis. The $\mathrm{AME}_{n}$ of barleys were higher for cockerels compared to broilers. Differences in amino acid digestibility of dicts measured from excreta and digesta varied for individual amino acids. The AID of alanine, glycine and methionine were higher than corresponding AED values. For other measured amino acids AED was higher than AID, the largest differences observed for cystine and aspartic acid.

KEY WORDS: amino acids, barley, digestibility, metabolizable energy, poultry, volume-weight

\section{INTRODUCTION}

In Northern Europe and Canada, barley is an important energy source in monogastric feeds. Broiler diets can contain up to $60 \%$ of barley. Barley protein contains more essential amino acids, e.g. methionine, lysine and threonine than

\footnotetext{
" Supported by Rehuraisio Ltd., Raisio, Finland
} 
wheat protein (Wallis, 1984). However, amino acid digestibility is lower for barley than wheat due to higher non-starch polysaccharide content (Wallis, 1984). The chemical composition and nutrient digestibility of barley vary greatly and are affected by several factors, such as variety, level of fertilization and growing conditions (Bach Knudsen et al., 1987; Fuller et al., 1989; Bulman and Smith, 1993). The economical value of barley is generally based on volume-weight (VW). An association between VW and chemical composition of barley has been extensively studied during the 1970s (Sibbald and Price, 1976a,b; Coates et al., 1977; Salo, 1978).

Under unfavourable weather conditions, barley starch content is low, the endosperm is undeveloped, grain is smaller and lighter and the portion of hull is larger. According to Salo (1978) VW of barley is positively related to starch and negatively related to crude fibre content. However, there is a lack of knowledge concerning the connection between $\mathrm{VW}$ and the nutrient digestibility and AMEvalue for poultry, despite measurements being reported for wheat (Wiseman, 2000).

In general, amino acid requirements for poultry are expressed as total amino acids (NRC 1994). In addition, amino acid digestibility measurements based on excreta (AED) were previously used to optimise poultry diets. However, in poultry, little or no amino acids are absorbed after the ileum, while considerable microbial protein degradation and synthesis occurs in the lower digestive tract which affects the determination of apparent digestibility coefficients (Parsons et al., 1982). In addition, faeces and urine are voided together but amino acid excretion to urine is commonly supposed to be negligible. Therefore, digestibility values measured from excreta are subjected to error and apparent digestibility of amino acids should be measured at the ileum (AID) (Moughan and Donkoh, 1991). Furthermore, the difference between AID and AED of amino acids varies depending on dietary ingredient and the amino acid in question (Williams, 1995; Ravindran et al., 1999). Currently, there are only a limited number of published reports of AID of amino acids in barley.

The aim of this study was to investigate the effect of VW on the AME of barley for poultry and the digestibility of amino acids. In addition, the difference between ileal and total digestibilities was determined in order to evaluate the contribution of the lower digestive tract to the digestibility of barley in broilers.

\section{MATERIAL AND METHODS}

Birds

For Experiment 1, a total of 185 d-old Ross broilers were obtained from a hatchery and raised in three-floor battery wire cages (size $47.5 \times 56 \times 40 \mathrm{~cm}$ ), five 
birds (two males and three females or two females and three males) per cage. One bird per cage (female or male) was killed for digesta viscosity determinations, so that equal numbers of both sexes per cage were used for excreta and digesta collections. Birds received standard broiler starter and grower diets (220 and $200 \mathrm{~g} / \mathrm{kg}$ of crude protein, respectively) from d 1 to $\mathrm{d} 14$ and from d 15 to d 21, respectively. Broilers were $22 \mathrm{~d}$ of age at the beginning of the experiment. The broiler house temperature was maintained at $19^{\circ} \mathrm{C}$ during the experimental period (from d 22) and light was controlled according to Ross-broiler breeders' instructions (20 h light (5-10 lux) and $4 \mathrm{~h}$ dark cycle).

In Experiment 2, a total of 36 adult ( 26 wk old) Leghorn cockerels were used. Birds were housed in digestibility cages $(30 \times 45 \times 50 \mathrm{~cm})$, one cock per cage at a temperature of $20^{\circ} \mathrm{C}$ under a $11 \mathrm{~h}$ light ( $7 \mathrm{lux}$ ) and $13 \mathrm{~h}$ dark cycle.

\section{Diets}

Barley (var. Kymppi) were harvested during year 1997. Barley samples were obtained from batches sent to Rehuraisio Ltd., Finland by contract-producers. A total of 200 samples were classified by VWs and 15 samples were randomly selected from classes for detailed analysis. Six samples were chosen for digestibility experiments based on VW and chemical composition of samples (Table 1). Object was to get barleys with different VWs but fairly uniform protein content. Experimental barleys were harvested during 1997, when weather conditions were rather dry (rain $385 \mathrm{~mm}$ and cumulative temperature $1504^{\circ} \mathrm{C}$ during the growing season (temperature over $5^{\circ} \mathrm{C}$ )). In Experiment 1 with broilers, six barleys with VWs of $53.4,60.6,62.6,64.6,68.6$ and $71.5 \mathrm{~kg} / \mathrm{hl}$ were used. In Experiment 2 with cockerels, the same barleys with the exception of barley with a VW of $60.6 \mathrm{~kg} / \mathrm{hl}$ were used. Barleys were ground before mixing using a $4.0 \mathrm{~mm}$ sieve (Pulverisette 15, Fritsch, Germany).

In both experiments, test diets contained $500 \mathrm{~g}$ of each barley sample and $500 \mathrm{~g}$ of basal diet (BD), on a DM basis. Diets were formulated to meet nutrient requirements of broilers (Tuori et al., 1996) and were fed without enzymes (Table 2). A semi-purified basal diet contained soyabean meal as the sole source of protein (Table 3). For all treatments in the broiler experiment, $1.7 \mathrm{~g} / \mathrm{kg}$ feed of chromium mordanted straw was used as indigestible marker $(0.2 \mathrm{~g} \mathrm{Cr} / \mathrm{kg}$ feed, Udén et al., 1980). Barleys and basal diet ingredients were mixed in a batch-mixer and pressed with cold air to $4 \mathrm{~mm}$ pellets (Amandus Kahl Laborpresse L175, Germany).

\section{Experimental procedures}

In experiment 1 at 22 day of live, five cages of five birds were randomly allocated to each of the six dietary treatments and the basal diet. Feed and water was 
TABLE 1

Composition of the tested barleys, g/kg dry matter (unless otherwise stated)

\begin{tabular}{|c|c|c|c|c|c|c|}
\hline Barley VW, kg/hl & 53.4 & 60.6 & 62.6 & 64.6 & 68.6 & 71.5 \\
\hline Barley WTK, g & 31.4 & 37.5 & 34.1 & 39.0 & 37.2 & 35.8 \\
\hline Dry matter, $\%$ & 88.49 & 88.10 & 88.51 & 88.43 & 88.35 & 89.99 \\
\hline Organic matter & 964.7 & 970.8 & 971.7 & 971.1 & 971.6 & 971.5 \\
\hline Ash & 35.3 & 29.2 & 28.3 & 28.9 & 28.4 & 28.5 \\
\hline Crude protein & 131.4 & 126.9 & 129.1 & 128.7 & 125.2 & 139.0 \\
\hline Crude fat & 29.0 & 29.4 & 30.2 & 30.6 & 30.5 & 31.3 \\
\hline Crude fibre & 62.6 & 55.7 & 60.8 & 52.2 & 48.8 & 44.8 \\
\hline $\mathrm{N}$-free extractives & 741.6 & 758.8 & 751.5 & 759.6 & 767.0 & 756.3 \\
\hline Starch & 585.4 & 610.8 & 606.2 & 645.2 & 624.9 & 611.8 \\
\hline NDF & 262.7 & 242.3 & 256.4 & 233.0 & 235.4 & 205.1 \\
\hline $\mathrm{ADF}$ & 66.5 & 64.6 & 65.4 & 61.4 & 57.2 & 49.1 \\
\hline Hemisellulose & 196.2 & 177.7 & 191.0 & 171.6 & 178.2 & 156.0 \\
\hline$\beta$-ghucan & 41.3 & 40.3 & 41.4 & 49.2 & 47.0 & 47.9 \\
\hline \multicolumn{7}{|l|}{ Amino acids } \\
\hline arginine & 6.5 & 6.3 & 6.3 & 6.3 & 6.3 & 6.6 \\
\hline histidine & 3.0 & 2.8 & 2.9 & 2.9 & 2.9 & 3.0 \\
\hline isoleucine & 4.1 & 3.9 & 4.0 & 3.8 & 3.8 & 4.3 \\
\hline leucine & 8.9 & 8.7 & 8.9 & 8.7 & 8.6 & 9.3 \\
\hline lysine & 4.2 & 4.0 & 4.2 & 4.0 & 4.0 & 4.3 \\
\hline methionine & 2.0 & 2.0 & 2.0 & 1.8 & 1.9 & 2.0 \\
\hline plicnylalanine & 6.5 & 6.4 & 6.5 & 6.5 & 6.4 & 7.0 \\
\hline threonine & 4.1 & 4.0 & 4.0 & 4.0 & 3.9 & 4.2 \\
\hline valine & 6.8 & 7.4 & 7.8 & 7.0 & 7.7 & 6.9 \\
\hline alanine & 5.2 & 5.1 & 5.1 & 5.0 & 4.9 & 5.2 \\
\hline aspartic acid & 7.2 & 7.0 & 7.1 & 6.9 & 6.9 & 7.5 \\
\hline cystine & 3.1 & 3.1 & 3.0 & 3.0 & 2.7 & 3.2 \\
\hline glutamic acid & 31.5 & 31.4 & 30.3 & 33.7 & 29.5 & 35.5 \\
\hline glycine & 5.3 & 5.2 & 5.2 & 5.1 & 5.1 & 5.3 \\
\hline proline & 15.1 & 15.5 & 14.8 & 16.1 & 14.1 & 17.0 \\
\hline serine & 5.3 & 5.3 & 5.3 & 5.3 & 5.1 & 5.6 \\
\hline tyrosine & 4.2 & 4.1 & 4.2 & 4.1 & 4.1 & 4.5 \\
\hline
\end{tabular}

$\mathrm{VW}=$ volume-weight, $\mathrm{WTK}=$ weight per $1,000 \mathrm{kernels}$

provided ad libitum. After a $5 \mathrm{~d}$ adaptation period, one bird per cage was killed for digesta viscosity determinations. Thereafter total excreta collection was carried out for $3 \mathrm{~d}$. That was followed by a further $2 \mathrm{~d}$ adaptation period, $24 \mathrm{~h}$ fasting and $4 \mathrm{~h}$ free access to feed after which birds were killed for ileal digesta collection. The trial lasted 13 days. Cages were divided into five blocks, each consisting of seven treatments. Feeding and killing were started at the same time for the whole block (one cage from each treatment). Time between blocks were $1 \mathrm{~h}$. Birds were 
TABLE 2

Composition of the experimental diets, $\mathrm{g} / \mathrm{kg}$ dry matter (unless stated otherwisc), for broilers and cockerels

\begin{tabular}{|c|c|c|c|c|c|c|c|c|c|c|c|c|c|}
\hline \multirow{3}{*}{$\begin{array}{l}\text { Diet } \\
\text { Barley VW }\end{array}$} & \multicolumn{7}{|c|}{ Experiment I } & \multicolumn{6}{|c|}{ Experiment 2} \\
\hline & 1 & 2 & 3 & 4 & 5 & 6 & 7 & I & 2 & 3 & 4 & 5 & 6 \\
\hline & $\mathrm{BD}$ & 53.4 & 60.6 & 62.6 & 64.6 & 68.6 & 71.5 & $\mathrm{BD}$ & 53.4 & 62.6 & 64.6 & 68.6 & 71.5 \\
\hline Dry matter,\% & 92 & 90 & 92 & 92 & 92 & 91 & 91 & 88 & 87 & 88 & 87 & 87 & 87 \\
\hline Crude protein & 308 & 218 & 222 & 222 & 217 & 215 & 218 & 173 & 158 & 157 & 169 & 155 & 161 \\
\hline Crude fibre & 46 & 50 & 42 & 48 & 43 & 43 & 43 & & & & & & \\
\hline Ether extract & 30 & 29 & 29 & 30 & 31 & 30 & 31 & & & & & & \\
\hline Ash & 89 & 64 & 66 & 61 & 69 & 61 & 60 & & & & & & \\
\hline \multicolumn{14}{|l|}{ Gross energy, } \\
\hline $\mathrm{MJ} / \mathrm{kg} \mathrm{DM}$ & 18.0 & 18.2 & 18.0 & 18.3 & 18.2 & 18.2 & 18.2 & 17.9 & 18.0 & 18.0 & 18.1 & 18.0 & 18.2 \\
\hline
\end{tabular}

TABLE 3

Composition of basal diet, $\mathrm{g} / \mathrm{kg}$ dry matter

\begin{tabular}{lcc}
\hline Experiment & Broilers (Experiment 1) & Cockerels (Experiment 2) \\
\hline Soyabcan meal & 625 & 170 \\
Barley starch & 314 & 790 \\
Limestone & 18 & 10 \\
Dicalcium phosphate & 30 & 20 \\
NaCl & 5 & 5 \\
DL-methionine & 2.0 & 0.5 \\
Trace mincral premix & 3.0 & 2.0 \\
Vitamin premix $^{2}$ & 3.0 & 3.0 \\
\hline
\end{tabular}

1 trace mineral premix supplied per $\mathrm{kg}$ of basal diet for broilers and cockerels, respectively (in $\mathrm{mg}$ ): $\mathrm{Ca}, 950$ and $630 ; \mathrm{Fc}, 43.8$ and $29.2 ; \mathrm{Cu}, 7.6$ and $5.1 ; \mathrm{Mg}, 75.4$ and $50.3 ; \mathrm{Zn}, 97.6$ and $65.1 ; \mathrm{I}, 0.7$ and $0.5 ; \mathrm{Se}, 0.3$ and 0.2

2 vitamin premix supplied per $\mathrm{kg}$ of basal diet for broilers and cockerels, respectively (in $\mathrm{mg}$ ): $\mathrm{Ca}$, 2.1 ; P, 8.9; vit. A, 18750 IU; vit. D 4650 IU; vit. E, 60.0; tocopherol, 54.0; phylloquinone, 7.5; thiamine, 4.5 ; riboflavin, 9.0 ; pyridoxine, 6.0 ; cyanocobalamin, 0.05 ; biotin, 0.45 ; folic acid, 1.5 ; niacin, 60.3 ; pantothenic acid, 22.5 , and antioxidants, 0.92

killed by stunning with carbon dioxide and subsequent neck dislocation. The ileum was dissected from Meckel's diverticulum to the ileo-caeco-colic junction and digesta was quantitatively collected from the distal $15 \mathrm{~cm}$ for viscosity and digestibility determinations. Viscosity of ileal digesta was measured after centrifugation (11 $600 \times \mathrm{g}, 3 \mathrm{~min}$ ) on a Brookfield Digital Viscometer (Brookficld Engineering Laboratories Inc., Stoughton, MA, USA) at $25^{\circ} \mathrm{C}$ with a Cone-Plate 40 spindel. Digesta of birds within a cage was pooled before chemical analysis. 
In Experiment 2, cockerels were divided into six equal blocks according to liveweight. Within a block, cages containing one bird were randomly allocated to six treatments. Feed and water was offered ad libitum. The trial lasted 9 days, that included $5 \mathrm{~d}$ adaptation and $4 \mathrm{~d}$ total excreta collection. Collection of excreta was performed as described for Experiment 1. For both experiments, birds were weighed at the beginning and end of the trial and at the beginning and end of excreta collection. Feed intake of each cage was recorded during the collection period and for broilers during the $4 \mathrm{~h}$ pre-slaughter period. Experimental procedures were evaluated and approved by the Animal Care Committee of the MTT Agrifood Research Finland.

\section{Chemical analysis}

Feed ingredients were sampled before mixing of experimental diets. Ileal digesta samples were freeze-dried and excreta samples were dried over night at $60^{\circ} \mathrm{C}$. All samples were ground to through a $1 \mathrm{~mm}$ sieve before analysis. Nitrogen analysis from excreta was conducted with fresh samples by the Kjeldahl-method and that from dried ileal digesta samples according to a Dumas based method using a Leco FP 428 nitrogen analyser (Leco Corp., St Joseph, USA). Proximate analysis was performed according to standard procedures (AOAC, 1990), crude fibre using method of Hirsjärvi and Andersen (1954), starch according to Bach Knudsen et al. (1987), neutral detergent fibre (NDF) according to Van Soest et al. (1991) and acid detergent fibre (ADF) and lignin according to Robertson and Van Soest (1981). Samples were hydrolysed with $4 \mathrm{M} \mathrm{HCl}$ before ether extract analysis. Gross energy were determined with IKA C 400 calorimeter (Janke and Kunkel $\mathrm{GmbH}$, Satufen, Germany) using benzoic acid as a calibration standard. Amino acids were determined according to official EC method (EC 1998), chromium according to Williams et al. (1962) and $\beta$-glucans according to McCleary and Codd (1991).

\section{Data analysis}

AID and AED of nutrients were calculated using $\mathrm{Cr}$ as an indigestible marker:

$$
\text { Apparent ileal or excreta digestibility }=\left[(\mathrm{N} / \mathrm{Cr})_{\mathrm{d}}-(\mathrm{N} / \mathrm{Cr})_{\mathrm{ic}}\right] /(\mathrm{N} / \mathrm{Cr})_{\mathrm{d}^{\prime}} \text {, }
$$

where $(\mathrm{N} / \mathrm{Cr})_{\mathrm{d}}=$ the dietary ratio of nutrient to $\mathrm{Cr}$ and $(\mathrm{N} / \mathrm{Cr})_{\mathrm{ic}}=$ the ratio of nutrient to $\mathrm{Cr}$ in ileal digesta or excreta.

Digestibilities of test barleys were calculated by difference using measured digestibility coefficients for $\mathrm{BD}$ :

Nutrient digestibility $=\left[\left(\mathrm{I}_{d} \times D_{d}\right)-\left(I_{b d} \times D_{\text {bd }}\right)\right] / I_{\text {barley }} \times 100$, 
where $I_{d}$ and $I_{b d}=$ intake of nutrient from diet and basal diet, $D_{d}$ and $D_{b d}=$ digestibility of nutrient in dict and in basal diet and $\mathrm{I}_{\text {barley }}=$ intake of nutrient from barley.

Apparent ME values of diets (AME) were calculated by subtracting the GE of excreta from GE intake divided by total dry matter intake. The AME values were corrected for zero nitrogen retention ( $\mathrm{AME}_{\mathrm{n}}$ ) assuming a value of $36.55 \mathrm{~kJ} / \mathrm{g}$ of nitrogen lost or retained (Titus et al., 1959). AME of barleys were calculated by difference method.

Experimental data was subjected to analysis of variance using the GLM procedure of SAS (1990) and the model which had the random effect of block and fixed effect of treatment (Snedecor and Cochran, 1989). Where appropriate, treatment means were compared using Tukey test. When AID and AED of amino acids were compared, the model included the random effect of digestibility, fixed effect of treatment and their interaction. In all cases, residuals were plotted against fitted values to ensure normality of experimental data.

\section{RESULTS}

VW did not affect liveweight gain or feed intake of broilers and cockerels (Table 4). The viscosity of ileal digesta was greatest in broilers fed barley of the highest VWs (68.6 and $71.5 \mathrm{~kg} / \mathrm{hl} ; \mathrm{P}<0.05)$. However, VW did not affect the AID of barley diets or barley samples calculated by difference in broilers (Table 4). In addition, nitrogen retention and $\mathrm{AME}_{\mathrm{n}}$ were not influenced by barley $\mathrm{VW}$ in broilers or cockerels. However, barley $\mathrm{AME}_{\mathrm{n}}$ varied between samples, being higher for cockercls (from 12.6 to $13.5 \mathrm{MJ} / \mathrm{kg} \mathrm{DM}$ ) compared to broilers (from 11.7 to $12.7 \mathrm{MJ} / \mathrm{kg} \mathrm{DM}$ ) (Table 4). In addition, in diets ME:GE ratio ranged from 0.61 to 0.64 and from 0.66 to 0.70 for broilers and cockerels, respectively.

VW did not affect the AID and AED of amino acids ( $P>0.05$ ) (Tables 5 and 6 ). No interactions between digestibility assay and amino acid digestibility were detected. Differences in amino acid digestibilities between digestibility assays varied for individual amino acids. In diets, AID of most amino acids tended to be lower for the basal compared to other diets. In contrast, AED of amino acids were the same for all diets. Only histidine, lysine and tyrosine digestibility coefficients were independent of the digestibility assay. The AID of alanine, glycine and methionine in diets were higher than corresponding AED values $(\mathrm{P}<0.001)$. For the other measured amino acids AED were higher than AID values $(P<0.05)$, with the largest differences observed for cystine and aspartic acid. The calculated AID values of some amino acids in barleys were over $100 \%$. However, digestibility assay had no effect on the digestibility of proline and tyrosine in barley. For other measured amino acids, AED was higher than AID $(\mathrm{P}<0.05)$, with the largest differences being observed for alanine, arginine, aspartic acid, lysine and valine. 
TABLE 4

Apparent ileal and excreta digestibility coefficients, digesta viscosity (centipoise) and apparent metabolizable energy values $(\mathrm{MJ} / \mathrm{kg} \mathrm{DM})$ of diets and barleys in broilers and cockerels

\begin{tabular}{|c|c|c|c|c|c|c|c|c|}
\hline $\begin{array}{l}\text { Dict } \\
\text { Barley VW }\end{array}$ & $\begin{array}{c}1^{\prime} \\
\mathrm{BD}\end{array}$ & $\begin{array}{c}2 \\
53.4\end{array}$ & $\begin{array}{c}3 \\
60.6\end{array}$ & $\begin{array}{c}4 \\
62.6\end{array}$ & $\begin{array}{c}5 \\
64.6\end{array}$ & $\begin{array}{c}6 \\
68.6\end{array}$ & $\begin{array}{c}7 \\
71.5\end{array}$ & SEM \\
\hline Broilers, $\mathrm{n}$ & & 5 & 5 & 5 & 5 & $5(4)^{2}$ & 5 & \\
\hline $\begin{array}{l}\text { liveweight, } g \\
\text { (age } 33 \text { days) } \\
\text { intake, }\end{array}$ & 1327 & 1306 & 1295 & 1351 & 1363 & 1307 & 1266 & 31.9 \\
\hline $\mathrm{g} \mathrm{DM} / \mathrm{kgW}^{0.75} / \mathrm{d}$ & 107 & 107 & 109 & 108 & 108 & 109 & 105 & 2.1 \\
\hline \multicolumn{9}{|l|}{ AID in diets } \\
\hline dry matter & 0.58 & 0.58 & 0.59 & 0.57 & 0.51 & 0.62 & 0.60 & 0.010 \\
\hline organic matter & 0.62 & 0.61 & 0.63 & 0.60 & 0.63 & 0.64 & 0.63 & 0.010 \\
\hline crude protein & 0.70 & 0.74 & 0.74 & 0.73 & 0.75 & 0.74 & 0.75 & 0.011 \\
\hline \multicolumn{9}{|l|}{ AID in barleys } \\
\hline dry matter & & 0.58 & 0.60 & 0.56 & 0.62 & 0.65 & 0.61 & 0.022 \\
\hline organic matter & & 0.61 & 0.63 & 0.58 & 0.63 & 0.66 & 0.63 & 0.021 \\
\hline crude protein & & 0.87 & 0.85 & 0.83 & 0.90 & 0.88 & 0.89 & 0.041 \\
\hline Viscosity, centipoise & & $8.2^{\mathrm{a}}$ & $8.8^{\mathrm{a}}$ & $8.2^{\mathrm{a}}$ & $9.3^{\mathrm{a}}$ & $28.6^{h}$ & $27.4^{b}$ & 3.50 \\
\hline $\begin{array}{l}\mathrm{AME}_{\mathrm{n}} \text { in diets, } \\
\mathrm{MJ} / \mathrm{kg} \text { DM }\end{array}$ & 10.6 & 11.3 & 11.3 & 11.3 & 11.1 & 11.6 & 11.5 & 0.14 \\
\hline $\begin{array}{l}\mathrm{AME}_{\mathrm{n}} \text { in barleys, } \\
\mathrm{MJ} / \mathrm{kg} \mathrm{DM}\end{array}$ & & 12.0 & 12.0 & 12.0 & 11.7 & 12.7 & 12.5 & 0.30 \\
\hline $\begin{array}{l}\text { Cockerels, } \mathrm{n} \\
\text { liveweight, g }\end{array}$ & & 5 & & 5 & 5 & 5 & 5 & \\
\hline (age 191 days) & 2059 & 2046 & & 2069 & 2029 & 2104 & 2040 & 218.6 \\
\hline $\begin{array}{l}\text { intake, } \mathrm{g} \mathrm{DM} / \mathrm{kgW}^{0.75} / \mathrm{d} \\
\mathrm{AME}_{\mathrm{n}} \text { in dicts, }\end{array}$ & 45 & 50 & & 49 & 49 & 48 & 47 & 6.59 \\
\hline $\begin{array}{l}\mathrm{MJ} / \mathrm{kg} \text { DM } \\
\mathrm{AME}_{\mathrm{n}} \text { in barlcys, }\end{array}$ & 11.9 & 12.4 & & 12.2 & 12.5 & 12.7 & 12.6 & 0.39 \\
\hline $\mathrm{MJ} / \mathrm{kg} \mathrm{DM}$ & & 13.0 & & 12.6 & 13.2 & 13.5 & 13.4 & 0.77 \\
\hline
\end{tabular}

${ }^{1}$ results from basal diet were not included in the statistical analysis

${ }^{2}$ only 4 obscrvations for viscosity determinations of treatment 5. SEM value for this parameter is 1.117 times greater than that reported in the table $\mathrm{VW}=$ volume-weight

ab values in the rows with a different letter are significantly different at $\mathrm{P}<0.05$ 
TABLE 5

Nitrogen retention of intake and apparent digestibility coefficients of amino acids of broiler diets (Experiment 1)

\begin{tabular}{|c|c|c|c|c|c|c|c|c|c|c|c|c|}
\hline $\begin{array}{l}\text { Amino } \\
\text { acid }\end{array}$ & VW & $\mathrm{BD}^{\prime}$ & 53.4 & 60.6 & 62.6 & 64.6 & 68.6 & 71.5 & SEM & Diet & Site & $\begin{array}{l}\text { Diet } \\
x \text { site }\end{array}$ \\
\hline \multicolumn{2}{|c|}{$\begin{array}{l}\text { N-re- } \\
\text { tention }\end{array}$} & 0.40 & 0.45 & 0.46 & 0.48 & 0.44 & 0.48 & 0.46 & 0.017 & ns & & \\
\hline \multirow[t]{2}{*}{ Ala } & $\mathrm{AED}$ & 0.70 & 0.68 & 0.67 & 0.69 & 0.66 & 0.68 & 0.68 & 0.013 & $\mathrm{~ns}$ & $* * *$ & ns \\
\hline & AID & 0.71 & 0.72 & 0.73 & 0.73 & 0.75 & 0.74 & 0.77 & 0.014 & & & \\
\hline \multirow[t]{2}{*}{ Arg } & AED & 0.83 & 0.83 & 0.82 & 0.83 & 0.82 & 0.83 & 0.83 & 0.006 & ns & $*$ & ns \\
\hline & AID & 0.75 & 0.80 & 0.79 & 0.80 & $0.8 !$ & 0.82 & 0.82 & 0.011 & & & \\
\hline \multirow[t]{2}{*}{ Asp } & AED & 0.75 & 0.76 & 0.75 & 0.77 & 0.75 & 0.75 & 0.76 & 0.010 & ns & $* * *$ & ns \\
\hline & AID & 0.64 & 0.69 & 0.68 & 0.69 & $0.7 !$ & 0.69 & 0.72 & 0.012 & & & \\
\hline \multirow[t]{2}{*}{ Glu } & $\mathrm{AED}$ & $0.78^{3}$ & 0.82 & 0.82 & 0.83 & 0.81 & 0.82 & 0.83 & 0.008 & ns & $* * *$ & ns \\
\hline & AID & $0.69^{2}$ & 0.78 & 0.78 & 0.79 & 0.79 & 0.78 & 0.81 & 0.011 & & & \\
\hline \multirow[t]{2}{*}{ Gly } & AED & 0.42 & 0.47 & 0.50 & 0.48 & 0.45 & 0.47 & 0.50 & 0.025 & ns & $* * *$ & ns \\
\hline & AID & 0.63 & 0.67 & 0.67 & 0.67 & 0.70 & 0.67 & 0.71 & 0.013 & & & \\
\hline \multirow[t]{2}{*}{ Cys } & AED & 0.60 & 0.68 & 0.66 & 0.66 & 0.63 & 0.65 & 0.66 & 0.017 & ns & $* * *$ & ns \\
\hline & AID & $0.47^{2}$ & 0.61 & 0.59 & 0.58 & 0.63 & 0.60 & 0.62 & 0.020 & & & \\
\hline \multirow[t]{2}{*}{$\mathrm{His}$} & AED & 0.81 & 0.79 & 0.79 & 0.79 & 0.79 & 0.78 & 0.80 & 0.011 & ns & ns & ns \\
\hline & AID & 0.76 & 0.78 & 0.77 & 0.77 & 0.78 & 0.78 & 0.80 & 0.011 & & & \\
\hline \multirow[t]{2}{*}{ Ile } & AED & 0.78 & 0.78 & 0.78 & 0.79 & 0.77 & 0.76 & 0.79 & 0.011 & ns & $*$ & ns \\
\hline & AID & 0.70 & 0.76 & 0.75 & 0.76 & 0.76 & 0.75 & 0.79 & 0.011 & & & \\
\hline \multirow[t]{2}{*}{ Leu } & AED & 0.80 & $0.8 i$ & 0.81 & 0.81 & 0.79 & 0.79 & 0.80 & 0.010 & ns & $* *$ & ns \\
\hline & AID & 0.72 & 0.78 & 0.78 & 0.78 & 0.79 & 0.78 & 0.79 & 0.010 & & & \\
\hline \multirow[t]{2}{*}{ Lys } & AED & 0.86 & 0.85 & 0.84 & 0.85 & 0.83 & 0.84 & 0.84 & 0.007 & ns & ns & ns \\
\hline & AID & $0.80^{2}$ & 0.84 & 0.83 & 0.84 & 0.85 & 0.85 & 0.86 & 0.008 & & & \\
\hline \multirow[t]{2}{*}{ Met } & AED & 0.84 & 0.81 & 0.81 & 0.82 & 0.81 & 0.81 & 0.80 & 0.009 & ns & $* * *$ & ns \\
\hline & AID & 0.84 & 0.85 & 0.85 & 0.84 & 0.86 & 0.85 & 0.86 & 0.010 & & & \\
\hline \multirow[t]{2}{*}{ Phe } & AED & 0.79 & 0.81 & 0.81 & 0.81 & 0.79 & 0.80 & 0.80 & 0.009 & ns & $* * *$ & ns \\
\hline & AID & 0.73 & 0.78 & 0.77 & 0.78 & 0.79 & 0.78 & 0.79 & 0.010 & & & \\
\hline \multirow[t]{2}{*}{ Pro } & AED & 0.76 & 0.81 & 0.80 & 0.80 & 0.79 & 0.80 & 0.77 & 0.011 & ns & $*$ & ns \\
\hline & AID & 0.72 & 0.80 & 0.78 & 0.77 & 0.79 & 0.79 & 0.77 & 0.013 & & & \\
\hline \multirow[t]{2}{*}{ Ser } & $\mathrm{AED}$ & 0.76 & 0.74 & 0.74 & 0.76 & 0.72 & 0.73 & 0.74 & 0.011 & ns & $* *$ & 11s \\
\hline & AID & 0.67 & 0.71 & 0.70 & 0.71 & 0.73 & 0.71 & 0.74 & 0.013 & & & \\
\hline \multirow[t]{2}{*}{ Thr } & AED & 0.70 & 0.71 & 0.70 & 0.72 & 0.69 & 0.69 & 0.70 & 0.013 & $\mathrm{~ns}$ & $* *$ & nIs \\
\hline & AID & 0.64 & 0.67 & 0.66 & 0.67 & 0.69 & 0.67 & 0.70 & 0.013 & & & \\
\hline \multirow[t]{2}{*}{ Tyr } & AED & 0.73 & 0.74 & 0.72 & 0.72 & 0.71 & 0.71 & 0.71 & 0.012 & ns & ns & nis \\
\hline & AID & 0.70 & 0.70 & 0.69 & 0.70 & 0.73 & 0.72 & 0.72 & 0.020 & & & \\
\hline \multirow[t]{2}{*}{ Val } & AED & 0.76 & 0.77 & 0.77 & 0.78 & 0.76 & 0.77 & 0.76 & 0.016 & ns & $* *$ & ns \\
\hline & AID & $0.67^{2}$ & 0.74 & 0.73 & 0.74 & 0.76 & 0.73 & 0.77 & 0.015 & & & \\
\hline
\end{tabular}

${ }^{1}$ data of basal dict was not included when experimental data was subjected to statistical analysis

${ }^{2}$ digestibility of the basal diet was different to that of the other diets $(\mathrm{P}<0.05)$

${ }^{3}$ digestibility of basal diet was statistically different to that of the diets 4 and $7(P<0.05)$

site $=\mathrm{AED}$ vs $\mathrm{AlD}, \mathrm{VW}=$ volume-weight, $\mathrm{BD}=$ basal diet

significance: $n s=$ non significant, ${ }^{*}=\mathrm{P}<0.05, * *=\mathrm{P}<0.01$ and $* * *=\mathrm{P}<0.001$ 
TABLE 6

Apparent digestibility coefficients of barley amino acids in broilers (Experiment 1)

\begin{tabular}{|c|c|c|c|c|c|c|c|c|c|c|c|}
\hline $\begin{array}{l}\text { Amino } \\
\text { acid }\end{array}$ & $\begin{array}{l}\text { VW } \\
\text { site }\end{array}$ & 53.4 & 60.6 & 62.6 & 64.6 & 68.6 & 71.5 & SEM & VW & Site & $\begin{array}{c}\text { VW* } \\
\text { site }\end{array}$ \\
\hline \multirow[t]{2}{*}{ Ala } & AED & 0.58 & 0.57 & 0.66 & 0.52 & 0.56 & 0.62 & 0.058 & $\mathrm{~ns}$ & $* * *$ & $\mathrm{~ns}$ \\
\hline & AID & 0.75 & 0.78 & 0.80 & 0.88 & 0.83 & 0.92 & 0.066 & & & \\
\hline \multirow[t]{2}{*}{ Arg } & AED & 0.83 & 0.80 & 0.83 & 0.78 & 0.84 & 0.83 & 0.031 & ns & $* * *$ & ns \\
\hline & AID & 1.06 & 1.00 & 1.01 & 1.08 & 1.04 & 1.10 & 0.064 & & & \\
\hline \multirow[t]{2}{*}{ Asp } & AED & 0.83 & 0.75 & 0.89 & 0.71 & 0.74 & 0.81 & 0.087 & ns & $* * *$ & ns \\
\hline & AID & 1.13 & 0.98 & 0.98 & 1.19 & 1.15 & 1.17 & 0.106 & & & \\
\hline \multirow[t]{2}{*}{ Glu } & AED & 0.94 & 0.92 & 0.94 & 0.88 & 0.91 & 0.92 & 0.023 & $\mathrm{~ns}$ & $* * *$ & ns \\
\hline & AID & 1.02 & 1.03 & 0.99 & 1.02 & 0.97 & 1.01 & 0.038 & & & \\
\hline \multirow[t]{2}{*}{ Gly } & AED & 0.64 & 0.79 & 0.70 & 0.55 & 0.68 & 0.70 & 0.110 & ns & $* *$ & ns \\
\hline & AID & 0.84 & 0.80 & 0.82 & 0.93 & 0.86 & 0.94 & 0.062 & & & \\
\hline \multirow[t]{2}{*}{ Cys } & $\mathrm{AED}$ & 0.82 & 0.77 & 0.77 & 0.69 & 0.74 & 0.76 & 0.047 & ns & $* *$ & ns \\
\hline & AlD & 0.86 & 0.82 & 0.79 & 0.92 & 0.87 & 0.89 & 0.060 & & & \\
\hline \multirow[t]{2}{*}{ His } & AED & 0.75 & 0.75 & 0.74 & 0.71 & 0.68 & 0.76 & 0.056 & $\mathrm{~ns}$ & $* *$ & ns \\
\hline & AID & 0.86 & 0.82 & 0.80 & 0.86 & 0.85 & 0.96 & 0.054 & & & \\
\hline \multirow[t]{2}{*}{ lle } & $\mathrm{AED}$ & 0.81 & 0.78 & 0.83 & 0.73 & 0.65 & 0.81 & 0.058 & $\mathrm{~ns}$ & $* * *$ & ns \\
\hline & AID & 0.99 & 0.92 & 0.96 & 1.01 & 1.03 & 1.02 & 0.058 & & & \\
\hline \multirow[t]{2}{*}{ Leu } & $\mathrm{AED}$ & 0.84 & 0.86 & 0.86 & 0.78 & 0.77 & 0.79 & 0.041 & ns & $* * *$ & ns \\
\hline & AID & 0.97 & 0.93 & 0.94 & 0.99 & 0.98 & 1.00 & 0.043 & & & \\
\hline \multirow[t]{2}{*}{ Lys } & $\mathrm{AED}$ & 0.76 & 0.70 & 0.81 & 0.65 & 0.69 & 0.72 & 0.053 & ns & $* * *$ & ns \\
\hline & AID & 1.16 & 1.09 & 1.12 & 1.21 & 1.26 & 1.25 & 0.067 & & & \\
\hline \multirow[t]{2}{*}{ Met } & AED & 0.73 & 0.71 & 0.77 & 0.74 & 0.70 & 0.70 & 0.041 & $\mathrm{~ns}$ & $* * *$ & ns \\
\hline & AlD & 0.86 & 0.85 & 0.84 & 0.92 & 0.86 & 0.91 & 0.039 & & & \\
\hline \multirow[t]{2}{*}{ Phc } & AED & 0.88 & 0.85 & 0.85 & 0.79 & 0.81 & 0.82 & 0.032 & ns & $* * *$ & ns \\
\hline & AID & 0.91 & 0.88 & 0.92 & 0.95 & 0.93 & 0.95 & 0.039 & & & \\
\hline \multirow[t]{2}{*}{ Pro } & AED & 0.88 & 0.87 & 0.87 & 0.82 & 0.86 & 0.79 & 0.027 & ns & ns & $\mathrm{ns}$ \\
\hline & AID & 0.92 & 0.88 & 0.84 & 0.90 & 0.89 & 0.86 & 0.035 & & & \\
\hline \multirow[t]{2}{*}{ Ser } & AED & 0.68 & 0.64 & 0.75 & 0.58 & 0.55 & 0.67 & 0.059 & ns & $* * *$ & ns \\
\hline & AID & 0.87 & 0.81 & 0.83 & 0.96 & 0.90 & 0.97 & 0.070 & & & \\
\hline \multirow[t]{2}{*}{ Thr } & AED & 0.75 & 0.69 & 0.78 & 0.66 & 0.65 & 0.72 & 0.061 & ns & $*$ & ns \\
\hline & AID & 0.78 & 0.74 & 0.76 & 0.87 & 0.78 & 0.87 & 0.065 & & & \\
\hline \multirow[t]{2}{*}{ Tyr } & AED & 0.77 & 0.68 & 0.69 & 0.64 & 0.63 & 0.63 & 0.054 & $\mathrm{~ns}$ & ns & ns \\
\hline & AID & 0.70 & 0.68 & 0.73 & 0.83 & 0.80 & 0.81 & 0.087 & & & \\
\hline \multirow[t]{2}{*}{ Val } & AED & 0.79 & 0.77 & 0.83 & 0.73 & 0.78 & 0.76 & 0.058 & $\mathrm{~ns}$ & $* * *$ & ns \\
\hline & AID & 0.96 & 0.89 & 0.90 & 1.00 & 0.92 & 1.00 & 0.058 & & & \\
\hline
\end{tabular}

$\mathrm{VW}=$ volume-weight

significance: $\mathrm{ns}=$ non significant, ${ }^{*}=\mathrm{P}<0.05,{ }^{*}=\mathrm{P}<0.01$ and ${ }^{* * *}=\mathrm{P}<0.001$ 


\section{DISCUSSION}

Metabolizable energy value of barley

In current study, no differences were found in adult cockerels and growing broilers in metabolizable energy value of barley samples. In addition, same barley samples were used in experiment with pigs and no differences in apparent ilcal amino acid digestibility coefficients between barleys were observed (Valaja et al., 1999). However, the $A M E_{n}$-values of barley obtained in the current study fall within the range previously reported by Sibbald and Price (1976a) and Kiiskinen (1981). In Sibbald and Price (1976a) the AME values of Canadian barleys (40 samples) for roosters varied between 9.9 and $14.5 \mathrm{MJ} / \mathrm{kg}$ sample due to variations in $\mathrm{VW}$ of between 45.7 and $71.4 \mathrm{~kg} / \mathrm{hl}$. Kiiskinen (1981) reported that differences in barley VW of between 48.8 and $62.5 \mathrm{~kg} / \mathrm{hl}$ ( 8 samples), were significantly correlated with AME in trial carried out with laying hens. In addition, Wiseman (2000) reported that VW did not affect AME values for wheats of VWs from 71 to $81.5 \mathrm{~kg} / \mathrm{hl}$. According to Coates et al. (1977), barley crude fibre content varied to a greater extent (from 4.5 to $7.2 \%$ ) than in the current experiment (from 4.5 to $6.3 \%$ ) and therefore a close relationship between metabolizable energy value and crude fibre content was in that experiment detected.

Differences in the digestibility of nutrients are caused by differences in barley composition, particularly fibre content (Hughes and Choct, 1999). Crude fibre is indigestible in small intestine. In the lower digestible tract crude fibre is used to a small extent in microbial fermentation reactions. In current experiment, barley with higher VW contained greater amounts of $\beta$-glucans and resulted in increased ileal digesta viscosity. Soluble carbohydrates, such as $\beta$-glucans, are not digested by endogenous enzymes, and therefore increase digesta viscosity and decrease nutrient digestibility and absorption in the small intestine (Hesselman and Aman, 1986). However, in the current study, barley $\beta$-glucan content had no affect on nutrient digestibility. In general, when VW of barley increases, the content of crude fibre decreases and starch increases. In current experiment, the content of crude fat also increased as VW increased. The greater content of starch and crude fat and lower content of crude fibre of the heavier barleys possible compensated the negative effects of $\beta$-glucans on nutrient digestibility and AME-value in the heavier barleys.

In the current study, $\mathrm{AME}_{\mathrm{n}}$ values for adult cockerels were higher than that of growing broilers. According to Scott et al. (1998), AME values increase as the ability of broilers to digest feed increases. Digesta transit time changes with age and is also dependent on dict composition and level of intake. Furthermore, young broilers have immature digestive tracts and lower endogenous enzyme activities compared to adult cockerels. The anti-nutritive effects of non-starch polysaccha- 
rides such as $\beta$-glucans diminishes after 3 weeks, and therefore AME values increase with maturity (Scott et al., 1998).

\section{Ileal vs total digestibility of amino acids}

In the current experiment, AID of amino acids in the basal diet tended to be lower compared to other diets. In contrast, AED of amino acids in basal diet did not vary from that of the other diets. Differences in AID and AED of amino acids in the basal diet resulted in a large variation in calculated barley digestibility values. The AID of amino acids in barleys appears to have been overestimated by the difference method due to large differences between the AID of amino acids of the basal diet compared to the other diets. Green et al. (1987) have noticed that the higher the intake of an amino acid the higher the apparent digestibility. At relative low intakes, small differences in supply will have a profound influence on differences in digestibility values, since endogenous losses contribute a large proportion of total excreta. However, the difference method assumes that digestibility coefficients are additive. In addition, supporting the arguments of Kadim and Moughan (1997), the digestibility of nutrients in the basal diet may have also decreased after incorporation with barleys because of the content of anti-nutritional $\beta$-glucans of barleys.

According to Williams (1995), relatively small differences between ileal and faecal digestibilities become more important when poorly and highly digestible ingredients are compared. Poorly digestible protein supplements undergo more microbial fermentation than highly digestible protein ingredients, which magnify the differences between ileal and faecal digestibilities (Ravindran et al., 1999). Deamination of amino acids liberates ammonia, which is not utilized by the bird, but is absorbed and excreted in the urine (Salter et al., 1974). In the presence of poorly digestible carbohydrates, microbial synthesis increases leading to a lower AED than AID of amino acids (Ravindran et al., 1999).

In the current study, the largest differences between AID and AED in barleys were for alanine, aspartic acid, glycine, cystine, lysine and methionine. Values for glycine are not reliable due to the production of glycine from acid hydrolysis of uric acid present in excreta (Soares et al., 1971). In addition, the content of methionine can be underestimated when acid hydrolysis is performed in the presence of carbohydrates (Blackburn, 1978). In wheat, ileal amino acid digestibility values have been much higher than values obtained in excreta indicating substantial microbial protein synthesis in the lower digestive tract (Ravindran et al., 1999). The mean excreta digestibility of amino acids in wheat was lower $(68 \%)$ than the ileal value $(81 \%)$. The AID of individual amino acids in wheat were 5 to $25 \%$ units higher than AED. In the study of Ravindran et al. (1999), differences were particularly evident for alanine, threonine, histidine, aspartic acid, lysine, valine and isolcucine. 
In conclusion, $\mathrm{VW}$ did not affect nutrient digestibility or $\mathrm{AME}_{\mathrm{n}}$ of barley. Barley $\beta$-glucan content and viscosity of ileal digesta increased with higher VWs. The $\mathrm{AME}_{\mathrm{n}}$ of barley for adult cockerels was higher than that for young broilers. Differences between AID and AED of amino acids in barleys were detected and they varied between individual amino acids.

\section{ACKNOWLEDGEMENTS}

Mrs. Ritva Muotila, Mrs. Kaarina Karppinen, Mr. Tapani Ratilainen and the laboratory staff of the Animal Nutrition Section of the Agrifood Research Finland are acknowledged for care of experimental animals and chemical analysis.

\section{REFERENCES}

AOAC, 1990. Official Methods of Analysis. Associations of Official Analytical Chemists. $15^{\text {th }}$ Edition. Arlington, VA

Bach Knudsen K.E., Åman P., Eggum P.O., 1987. Nutritive value of Danish grown barley varieties. I. Carbohydrates and other major constituents. J. Cereal Sci. 6, 173-186

Blackburn S., 1978. Amino Acid Detcrmination: Methods and Techniques. Marcel Dekker, New York

Bulman P., Smith D., 1993. Accumulation and redistribution of dry matter and nitrogen by spring barley. Agron. J. 85, 1114-1121

Coates B.J., Slinger S.J., Summers J.D., Bayley H.S., 1977. Metabolisable energy values and chemical and physical characteristics of wheat and barley. Can. J. Anim. Sci. 57, 195-207

EC, 1998. Commission Directive 98/64/EC of 3 September 1998 establishing community methods of analysis for the determination of amino acids, crude oils and fats, and olaquindox in feeding stuffs and amending Directive 71/393. EEC. Off. J. Eur. Comm. L257, 14-28

Fuller M.F., Cadenhead A., Brown D.S., Brewer A.C., Carver M., Robinson R., 1989. Varietal differences in the nutritive value of cereal grains for pigs. J. Agr. Sci. 113, 149-163

Green S., Bertrand S.L., Duron M.J.C., Maillard R., 1987. Digestibilities of amino acids in maize, wheat and barley meals determined with intact and caecotomised cockerels. Brit. Poultry Sci. $28,631-641$

Hesselman K., Aman P., 1986. The effect of $\beta$-glucanase on the utilization of starch and nitrogen by broiler chickens fed on barley of low- or high-viscosity. Anim. Feed Sci. Tech. 15, 83-93

Hirsjärvi V.P., Andersen L., 1954. Über die Rohfaserbestimmung 11. Z. Anal. Chem. 141, 348-361

Hughes R.J., Choct M., 1999. Chemical and physical characteristics of grains related to variability in energy and amino acid availability in poultry. Aust. J. Agr. Res. 50, 689-701

Kadim I.T., Moughan P.J., 1997. lleal amino acid digestibility assay for growing meat chicken effect of the imposition of a fasting period and the nature of the test diet. Brit. Poultry Sci. 38, $285-290$

Kiiskinen T., 1981. Possibilities to estimate feeding value of grain (in Finnish). Agricultural Research Centre of Finland, November $24^{\text {th }}$ 
McCleary B.V., Codd R., 1991. Measurement of (1-3)(1-4)-B-D-glucan in barley and oats: a streamlined enzymatic procedure. J. Sci. Food Agr. 55, 303-312

Moughan P.J., Donkoh A., 1991. Anino acid digestibility in non-ruminants - a review. In: D.J. Farrel (Editor). Recent Advances in Animal Nutrition in Australia. Armidale, New South Wales, University of New England, pp. 172-184

NRC, 1994. Nutrient Requirements of Poultry. $9^{\text {th }}$ revised Edition. National Research Council. Subcommittee on Poultry Nutrition. National Academy Press, Washington, DC

Parsons C.M., Potter L.M., Brown R.D., 1982. Effects of dictary protein and intestinal microflora on excretion of anino acids in poultry. Poultry Sci. 61, 939-946

Ravindran V., Hew L.I., Ravindran G., Bryden W.L., 1999. A comparison of ileal digesta and cxcreta analysis for the determination of amino acid digestibility in food ingredients for poultry. Brit. Poultry Sci. 40, 266-274

Robertson J.B., Van Soest P.J., 1981. The detergent system of analysis and its application to human foods. In: W.D.T. James, O. Theander (Editors). The Analyses of Dietary Fiber in Foods. Marcell Dekker, New York, pp. 123-158

Salo M.-L., 1978. Relationships between physical and chemical characteristics and calculated metabolizable energy values in barley and oats with highly variable volume weights. J. Sci. Agr. Soc. Finland 50, 276-284

Salter D.N., Coates, M.E., Hewitt D., 1974. The influence of gut microflora on the digestion of dietary and endogenous proteins: studies on the amino acid composition of the excreta of germfree and conventional animals. Brit. J. Nutr. 31, 307-318

SAS, 1990. SAS/STATß User's quide, Version 6. 4th Edition. Volumes 1-2, SAS Institute Inc., Cary, NC

Scott T.A., Silversides F.G., Classen H.L., Swift M.L., Bedford M.R., 1998. Comparison of sample source (excreta or ileal digesta) and age of broiler chick on measurement of apparent digestible energy of wheat and barley. Poultry Sci. 77, 456-463

Sibbald I.R., Price, K., 1976a. Relationships between metabolizable energy values for poultry and some physical and chemical data describing Canadian wheats, oats and barleys. Can. J. Anim. Sci. $56,255-268$

Sibbald I.R., Price K., 1976b. True metabolisable energy values for poultry of Canadian baricys measured by bioassay and predicted from physical and chemical data. Can. J. Anim. Sci. 56, $775-782$

Snedecor G.W., Cochran W.G., 1989. Statistical Methods. 8th Edition. Iowa State University Press, Ames

Soares J.H., Miller D., Fitz N., Sanders M,, 1971. Some factors affecting the biological availability of amino acids in Iish protein. Poultry Sci. 50, 1134-1143

Titus H.W., Mehring A.L., Johnson D. Jr., Nesbitt L.L. Jr., Tomas T., 1959. An evaluation of MCF (Micro-Cel-Fat), a new type of fat product. Poultry Sci. 38, 1114-1119

Tuori M., Kaustell K., Valaja J., Aimonen E., Saarisalo E., Huhtanen P., 1996. Feeding Tables and Recommendations (in Finnish). Yliopistopaino, Helsinki

Udén P., Colucci P.E., Van Socst P.J., 1980. Investigation of chromium, ccrium and cobalt as digesta flow markers in the rate of passage studies. J. Sci. Food Agr. 31, 625-632

Valaja J., Partanen K., Siljander-Rasi H., Jalava T., Vasara A., 1999. Effect of barley volume-weight on the apparent digestibility and utilisation of protein in growing pigs. In: Protein Metabolism and Nutrition. Book of Abstracts of the VIIIth International Symposium on Protein Metabolism and Nutrition. EAAP, Aberdeen (UK), p.46

Van Soest P.J., Robertson J.B., Lewis B.A., 1991. Methods for dietary fiber, neutral detergent fiber and non-starch polysaccharides in relation to animal nutrition. J. Dairy Sci. 74, 3583-3597 
Wallis I.R., 1984. The digestibility of amino acids in cereal grains. In: Proceedings of the Symposium at the Poultry Husbandry Research Foundation, University of Sydney, Paper No 14, p.19

Williams C.H., David D., Riismaa O., 1962. The determination of chromic oxide in faeces samples by atomic absorption spectrometry. J. Agr. Sci. 59, 381-385

Williams, P.E.V., 1995. Digestible amino acids for non-ruminants animals: theory and recent advances. Anim. Feed Sci. Tech. 53, 173-187

Wiseman J., 2000. Correlation between physical measurements and dietary energy values of wheat for poultry and pigs. Anim. Feed Sci. Tech. 84, 1-11

\section{STRESZCZENIE}

\section{Wplyw ciężaru objętościowego jęczmienia na pozorną strawność jelitową i calkowitą amino- kwasów oraz jego wartość energetyezną dla drobiu}

W doświadczeniu przeprowadzonym na 185 kurczętach brojlerach Ross, w wicku 22 dni, oraz 36 dorosłych kogutach Leghornach badano wpływ ciężaru objętościowego (od 53,4 do 75,1 $\mathrm{kg} \mathrm{h.'1)}$ na pozorną strawność całkowitą (AED) skłađników pokarmowych oraz wartość energetyczną (energii netto, $\mathrm{AME}_{\mathrm{n}}$ ) jęczmienia. Poza tym, na brojlerach, oznaczono pozorną strawność jelitową (AID) oraz AED aminokwasów. Ptaki żywiono półsyntetyczną dietą podstawową zawierającą śrutę sojowa, jako żródło białka ( $w$ ilości 300 i $170 \mathrm{~g} \mathrm{~N} \mathrm{x} 6,25 \mathrm{~kg}^{-1}$ w dietach, odpowiednio dla brojlerów i kogutów), lub dietą podstawową z ocenianym jęczmieniem w proporcji 50:50 (s.m.). AID i AED składników pokarmowych oznaczano metodą wskaźnikową, stosując jako wskaźnik słomę traktowaną chromem, AID składników pokarmowych metodą ubojową.

Ciçżar objętościowy jęczmienia nie miał wplywu na wartość AID oraz AED u brojlerów, a także na wartość energii metabolicznej ( $\mathrm{AME}_{\mathrm{n}}$ ) dla brojlerów $\mathrm{i}$ kogutów. $\mathrm{AME}_{\mathrm{n}}$ jęczmienia byla wyższa dla kogutów niż brojlerów. Różnice w strawności całkowitej i jelitowej aminokwasów diet były zróżnicowane dla poszczególnych aminokwasów. AID alaniny, glicyny i metioniny była wyższa niż AED. Dla pozostałych, oznaczanych aminokwasów, wartości AED były wyższe niż AID; największe różnice stwierdzono dla cystyny $i$ kwasu araginowego. 